\title{
Research on feeder network design: a case study of feeder service for the port of Kotka
}

\author{
Yisong Lin ${ }^{1}$, Xuefeng Wang ${ }^{1}$, Hao Hu ${ }^{2}$ and Hui Zhao ${ }^{3^{*}}$
}

\begin{abstract}
By exemplifying the feeder service for the port of Kotka, this study proposed a multi-objective optimization model for feeder network design. Innovative for difference from the single-objective evaluation system, the objective of feeder network design was proposed to include single allocation cost, intra-Europe cargo revenue, equipment balance, sailing cycle, allocation utilization, service route competitiveness, and stability. A three-stage control system was presented, and numerical experiment based on container liner's real life data was conducted to verify the mathematical model and the control system. The numerical experiment revealed that the three-stage control system is effective and practical, and the research ideas had been applicable with satisfactory effect.
\end{abstract}

Keywords: Feeder network, Single-objective, Multi-objective, Grey relation

\section{Introduction}

An obvious change in the container shipping industry is the upsizing of container vessels. According to industry consultant Alphaliner, container vessels over 10,000 TEU (Twenty-Foot Equivalent Unit) account for 35\% of the global fleet. With increasing usage of mega container vessels, cargo consideration at transshipment ports is now more important [1]. This transshipment may result from the limitation of port facilities or the economic evaluation of the market the port serves. The feeder line refers to the service routes that provide connection with trunk lines and plays an important part in transshipment. The feeder line service should not only realize efficient connection, but also expand service routes and feed the capacity. The competitiveness and stability of feeder networks are vital to the entire service network. However, there are few previous studies on feeder network design. The uniqueness of the feeder network design is not reflected in the evaluation system as current research takes trunk lines as a research

\footnotetext{
*Correspondence: zhaohuimtfy@163.com

${ }^{3}$ Department of Civil and Environmental Engineering, National University of Singapore, Singapore, Singapore

Full list of author information is available at the end of the article
}

object. In addition, the current research seems to be single objective as it evaluates cost or revenue, which is inconsistent with the characteristics of the participative observation. A multi-objective evaluation system is necessary to improve the current research, and this study intends to cultivate new ground in the current literature. We proposed a new optimization model from an actual case study of feeder network design for the port of Kokta, which proved to be effective through numerical experiment based on real life data.

Our main contribution is threefold. First, we propose a threex-stage control system for feeder network design, of which the main concepts are different from those of trunk lines. This solves the limitation for lack of evaluation of existing public services before the optimization model was proposed. The three-stage control system more realistically simulates the real decision-making process as the numerical experiment was derived from an author-involved case. Secondly, we propose a multi-objective decisionmaking system for feeder network design. This fills the current research gap that the optimization models were established via the single-objective evaluation of cost minimization or revenue maximization. Thirdly, we first 
propose including short-leg cargos (in this case, intraEuropean cargos) in the feeder network evaluation. This means we evaluate both long-haul and short-leg cargos in the shipping network design, which fills the current research gap regarding short-leg cargos.

The remainder of the paper is organized as follows. Section 2 presents a literature review and analyzes the research gap. Section 3 discusses the feeder network design problem. Section 4 formulates a feeder network design model and proposes alternatives based on historical data from a case study. Section 5 analyzes the results and investigates the underlying reason. Section 6 presents concluding remarks.

\section{Literature review}

In recent decades, the service network design problem has drawn significant attention in maritime studies. We first introduce some studies on general network design problem in container shipping. An example of a study analyzing a hub-and-spoke network design is an article by Gelarth, Maculan, and Mahey [2] which studied these two aspects in regards to container shipping. They proposed a mixed integer linear programming model and a Lagrangian decomposition approach was adopted as a solution. Information regarding the general problem of fleet deployment focusing on trunk and feeder lines can be found in the following studies: Everett et al. [3] (the first to study the fleet deployment problem), and Perakis and Jaramillo [4] who further expanded the research in this field. Interested readers can refer to the study by Meng et al. [5] for an overview of these studies.

Network design problem always examined considering cargo routing and some other practical factors. HwaJoong, Lee, and Tae-Woo [6] investigated the potential trunk lines and transshipment flows in the network design problem. In an effort to make the network design problem more practical, Shintani et al. [7] examined the network design problem with empty container repositioning. Santini, Plum, and Ropke [8] investigated a feeder network design by considering the operational characteristics. The container transport demand is uncertain during network design and cargo assignment periods [9]. Some studies used this uncertain demand as an input to model a stochastic cargo assignment problem. Meng, Wang, and Wang [10] developed a two-stage integer programming model to examine the fleet deployment and routing management problems over a shortterm planning horizon. There are also studies addressing inland waters and special waterways. Zheng and Yang [11] studied the network design for container shipping along the Yangtze River. The study proved economies of scale do exist on certain segments of the Yangtze River's service network. Zhao, $\mathrm{Hu}$, and Lin [12] studied the network design problem in the context of the Northern Sea
Route. They used a two-stage model where the first stage involved selecting a set of ports and the second stage involved designing the network.

We identified the following gaps in the current research on container liner shipping practices:

First, a single decision-making objective does not reflect the multi-objective behaviors of liner shipping in practice. The current research was based largely on the maximization of revenue, profit, or minimization of cost (e.g.,Hwa-Joong et al. [6] and Santini et al. [8]). However, in practice, the decision objective was made in reference to a host of factors including: cost, sailing cycle, equipment balance, allocation utilization, service route competitiveness, and stability. The equipment balance and allocation utilization assess the corresponding capability of the empty container provision and resource utilization efficiency. A single-objective decision-making process is not comprehensive enough and does not consider all the necessary variables.

Second, the implicit hypothesis of these studies was to allocate the vessels within specific calling ports. However, there is no comparison between the designed service network and the exchanging service routes from shipping alliance members or the common feeders. This may lead to one-sided conclusion.

Thirdly, most of the existing research focused on trunk lines but rarely on feeder lines. The different characteristics of feeder lines spur different research ideas. Santini et al. [8] proved that it was unnecessary to consider transshipment in feeder network design. However, the other characteristics of feeder network design were not studied.

In particular, to the best of our knowledge, no research has examined feeder network design from the viewpoint of intra-Europe or intra-Asia business position rather than just the connection for the trunk line. This is precisely where the contribution of the study lies.

\section{Problem description}

The large scale of container vessels has significantly changed the service network design, resulting in the hub-andspoke system in widely application. Konings et al. [13] concluded that feeder vessel operators benefit from the shorter turnaround times and productivity improvement in the hub-and-spoke system. The port of Kotka (Finland) is a typical out port in the hub-and-spoke network. As ocean carriers do not provide direct service to Kotka on the main east-west trade lanes, the port is heavily reliant on the feeder service from the hub ports of Rotterdam (the Netherlands) and Hamburg (Germany). Feeder liner companies such as Unifeeder and Xpress provide regular services to connect the port of Kotka with various ports in the Netherlands, Germany, Russia, Poland, and Denmark. 
Figure 1 presents a main service route in the Baltic Sea ports.

The common feeder services extend the hinterland market to out ports and lay a foundation for improving vessel utilization. However, an ocean carrier's individual demand cannot be satisfied as a result of the common feeder services'sailing frequency, calling ports and delivery time are designed by the common operators. In addition, ocean carriers have limitations in exploiting intra regional cargos due to the fact that short-leg slots are restricted. Carriers are also under continual cost pressure due to the fact that feeder vessel operators are relatively concentrated in certain geographical areas.

The ocean carrier Company A used to connect the port of Kotka through common feeder services by transshipment from the port of Hamburg and Rotterdam. This limitation became more pronounced with the upgrading of fleet capacity deployed in Europe and the Mediterranean region.

Company A kept statistics on its cargo volume and found that the port of Kotka's average import and export cargo volume only reached between 324 TEU and 370 TEU per week. This quantity is not adequate to support its own feeder service; however, it seems to be a practicable solution if the feeder service also connects with various ports in Denmark, Poland and Russia. In addition, having its own feeder service can also provide the company a path for empty container repositioning among different ports, and make it possible to develop the Intra-European business. The decision to move forward with its own feeder service hinges on whether it is more cost-efficient and competitive when compared to the common feeder service, but there are other factors to consider, as well. Given this complexity, it is important to develop a robust decision-making process that takes into account multiple key variables including: cost, equipment balance, allocation utilization and IntraEuropean cargo revenue, among others. We present a three-stage control method addressing this issue.

\section{Methodology}

Our recommendation is a three-stage optimization model analyzing the decision-making process based on the relevant observations. The first stage calculates the historical cargo volume transported by Company A on possible calling ports. We make an evaluation of the cost competitiveness of the company's own feeder service, comparing it to the common feeder service by assigning appropriate vessel types according to the historical cargo volume. The second stage presents an optimization model and proposes the alternative of a feeder service for the port of Kotka. We present the difference in the decision-making process by evaluating the revenue of intra-European cargos compared to traditional methods. The third stage proposes a multi-objective evaluation system for

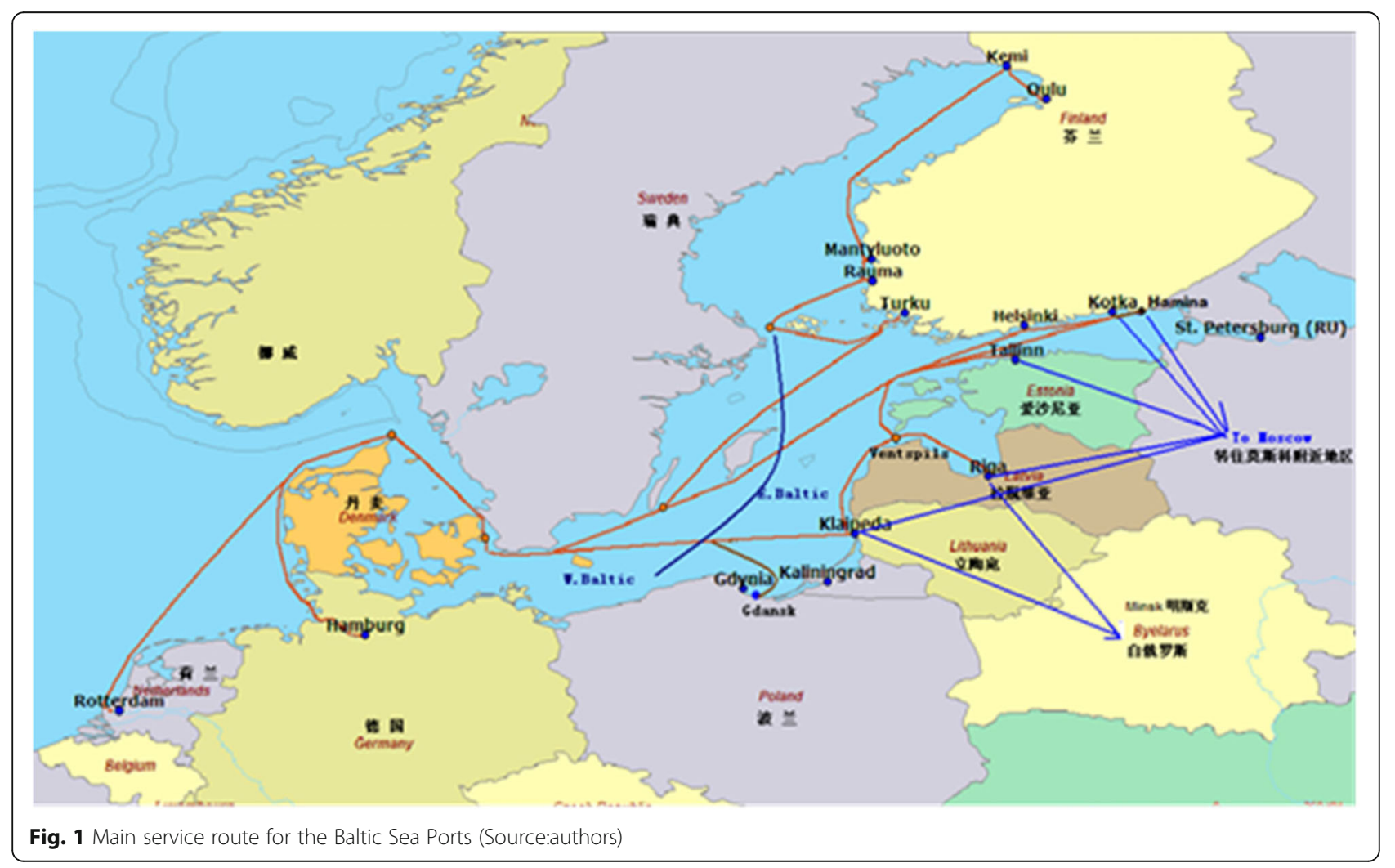


the alternative schemes through Grey correlation combining the indicators of cost, sailing cycle, equipment balance, service route competitiveness, stability, and Intra-European cargo revenue.

\subsection{Data}

The port of Kotka can connect with various ports in the Netherlands, Germany, Russia, Poland, and Denmark. Therefore, it is worth evaluating the cargo volume transported by Company A in these ports to identify the possible calling ports for cost comparison. Table 1 presents the cargo volume transport by Company A for 2018.The port of Hamburg is chosen as the transit hub of the feeder line service in line with cost comparison and distance between the ports of Hamburg and Rotterdam. The loading and discharging rates of Hamburg and Rotterdam port are basically the same. However, the port of Rotterdam is about 100 nautical miles away from Hamburg. Feeder vessels can enter the Baltic Sea through the Kiel Canal from the port of Hamburg.

According to the navigation requirements of Kiel Canal, the maximum scale of vessels passing through the canal is $235 \mathrm{~m}$ in length, $32.5 \mathrm{~m}$ in width, and $40 \mathrm{~m}$ in clear height of water surface. By evaluating the cargo transported by Company A at present, the available vessel types are 900TEUand 1500TEU. Table 2 presents the cost details under the two available vessel types. As the single allocation cost, the larger vessel for Company A's own feeder service is competitive.

The rate offered by common feeder liner companies to Company A was USD244/TEU for fully loaded containers and USD200/TEU for empty containers. The loading and discharging rate under ocean carrier's own feeder service is USD140/TEU for fully loaded containers and USD80/TEU for empty containers. Therefore, we calculate the cost difference for common and own feeder services under different allocation levels.
Table 3 presents the cost difference between own and common feeder services under different allocation lifting.

From the cost comparison in Table 3, we can conclude the own feeder service is more competitive than common feeder service only when the head haul allocation lifting is higher than $90 \%$. The head haul cargo to the ports of Kotka and St Petersburg transported by Company A was adequate to support an own feeder service (average 1043TEU/week calculated by Table 1). In addition, the own feeder service is beneficial to develop the intra-European business and to reposition empty containers between surplus and shortage areas. It also provides a potential option of slot exchange with common feeder companies on other service routes, or to improve the bargaining power in contract negotiation. Therefore, it is feasible to operate an own service route. We discuss the potential network design schemes below.

\subsection{Alternatives for feeder network design}

The objective of the model is to maximize the revenue subtracting the feeder network cost. What makes our model different from those in the literature is that we calculate the revenue generated not only from the hub port to the out ports, but also for between the short-leg ports.

The notation of variables and parameters for the model in this study are defined as follows.

$\mathrm{i} \in \mathrm{I}, \mathrm{j} \in \mathrm{J}$ : Ports in the network; $\mathrm{W}_{\mathrm{ij}}^{\mathrm{f}}$ : Fully loaded containers from port $i$ to port $j, i=0$ represents the hub port;

$\mathrm{W}_{\mathrm{ij}}^{\mathrm{e}}$ : Empty containers from port $\mathrm{i}$ to port $\mathrm{j}, \mathrm{i}=0$ represents the hub port;

$A_{i j}^{f}$ : Average weight of fully loaded containers from port i to port j;

Table 1 Cargo Volume Transported by Company A for year 2018. (Source: authors)

\begin{tabular}{|c|c|c|c|c|c|}
\hline Country & Import or Export & Ports & 20 Feet & 40 Feet & Total TEU \\
\hline \multirow[t]{3}{*}{ Denmark } & Import & Aarhus/Copenhagen & 4506 & 3273 & 11,052 \\
\hline & Export & Aarhus/Copenhagen & 2458 & 3144 & 8746 \\
\hline & Total & & 6964 & 6417 & 19,798 \\
\hline \multirow[t]{3}{*}{ Finland } & Import & Kotka & 4420 & 6220 & 16,860 \\
\hline & Export & Kotka & 4623 & 7319 & 19,261 \\
\hline & Total & & 4043 & 8539 & 21,121 \\
\hline \multirow[t]{3}{*}{ Poland } & Import & Gdynia & 2673 & 1484 & 5641 \\
\hline & Export & Gdynia & 136 & 433 & 1002 \\
\hline & Total & & 2809 & 1917 & 6643 \\
\hline \multirow[t]{3}{*}{ Russia } & Import & ST Petersburg & 6500 & 15,441 & 37,382 \\
\hline & Export & ST Petersburg & 1502 & 2719 & 6940 \\
\hline & Total & & 3002 & 13,160 & 29,322 \\
\hline
\end{tabular}


Table 2 Cost Details under Two Available Vessel Types for Possible Own Feeder Service. (Source: authors)

\begin{tabular}{|c|c|c|}
\hline Vessel Type & $\begin{array}{l}1 * 900 \text { TEU } \\
\text { Vessel }\end{array}$ & $\begin{array}{l}1 * 1500 \text { TEU } \\
\text { Vessel }\end{array}$ \\
\hline \multicolumn{3}{|l|}{ Vessel Cost } \\
\hline Vessel Rental Cost & USD 6000/Day & USD 7500/Day \\
\hline Full Voyage Time & 7Day & 7 Day \\
\hline Vessel Cost in Total & $\begin{array}{l}\text { USD 42000/ } \\
\text { Sailing }\end{array}$ & USD 52500/Sailing \\
\hline
\end{tabular}

Fuel cost

\begin{tabular}{|c|c|c|}
\hline Fuel Consumption on Sailing & 30 Ton/Day & 40 Ton/Day \\
\hline $\begin{array}{l}\text { Fuel Consumption on } \\
\text { Berthing }\end{array}$ & 2 Ton/Day & 2 Ton/Day \\
\hline Sailing Time on Sea & 4.5 day & 4.5 day \\
\hline Berthing Time on Port & 2.5 Day & 2.5 Day \\
\hline Price of Heavy Oil & USD 650/Ton & USD 650/Ton \\
\hline Price of Light Oil & USD 1000/Ton & USD 1000/Ton \\
\hline uel Cost in Total & USD 92750 & USD 122000 \\
\hline \multicolumn{3}{|l|}{ ort Cost } \\
\hline Port Cost of Hamburg & USD 13000 & USD 14000 \\
\hline Port Cost of Kiel Canal & USD 15000 & USD 16000 \\
\hline Port Cost of Kotka & USD 13000 & USD 14000 \\
\hline Port Cost of ST Petersburg & USD 12000 & USD 13000 \\
\hline ort Cost in Total & USD 53000 & USD 57000 \\
\hline otal Sailing Cost & USD 187750 & USD 231500 \\
\hline vailable Capacity & 700 TEU & 1050 TEU \\
\hline ingle Allocation Cost & USD 268 & USD 220 \\
\hline
\end{tabular}

$R_{i j}^{f}$ : Average revenue from port $i$ to port $j$ for fully loaded containers;

$\mathrm{R}_{\mathrm{ij}}^{\mathrm{e}}$ : Average revenue from port $\mathrm{i}$ to port $\mathrm{j}$ for empty containers;

$\mathrm{P}_{\mathrm{ij}}^{\mathrm{if}}$ : Fully loaded container's loading and discharging fee rate for port $i$ on service leg from port $i$ to port $j$;

$\mathrm{P}_{\mathrm{ij}}^{\mathrm{ie}}$ : Empty container's loading and discharging fee rate for port $\mathrm{i}$ on service leg from port i to port $\mathrm{j}$;

$\mathrm{T}_{\mathrm{ij}}^{\mathrm{i}}$ : Port and canal charges for port $\mathrm{i}$ on service leg from port i to port j;

$D_{\mathrm{ij}}$ : Distance from port $\mathrm{i}$ to port $\mathrm{j}$;

$\mathrm{S}_{\mathrm{ij}}$ : Vessel speed from port $\mathrm{i}$ to port $\mathrm{j}$;

$\mathrm{F}_{\mathrm{ij}}$ : Vessel's fuel consumption from port i to port $\mathrm{j}$;

$\mathrm{L}_{\mathrm{ij}}$ : Vessel's fuel consumption on berthing for any port between port i to port j;

$\mathrm{B}_{\mathrm{h}}$ : Price of heavy oil (Calculated by $\$ /$ Ton);

$\mathrm{B}_{1}$ : Price of light oil (Calculated by $\$ / T$ Ton);

V: Vessel's cost (Calculated by vessel rental cost and voyage time in this case);

S: Vessel's capacity (Calculated by the allocation in TEU).

DW: Vessel's weight capacity (Calculated by the allocation in Ton).

The objective function is to achieve maximization by subtracting the feeder network cost from the revenue:

$$
\max \sum\left\{\left(\mathrm{W}_{\mathrm{ij}}^{\mathrm{f}} * \mathrm{R}_{\mathrm{ij}}^{\mathrm{f}}+\mathrm{W}_{\mathrm{ij}}^{\mathrm{e}} * \mathrm{R}_{\mathrm{ij}}^{\mathrm{e}}\right)-\left(\mathrm{V}+\mathrm{W}_{\mathrm{ij}}^{\mathrm{f}} * \mathrm{P}_{\mathrm{ij}}^{\mathrm{if}}+\mathrm{W}_{\mathrm{ij}}^{\mathrm{e}} * \mathrm{P}_{\mathrm{ij}}^{\mathrm{ie}}+\mathrm{F}_{\mathrm{ij}} * \mathrm{~B}_{\mathrm{h}}+\mathrm{L}_{\mathrm{ij}} * \mathrm{~B}_{1}+\mathrm{T}_{\mathrm{ij}}^{\mathrm{i}}\right)\right\}
$$

s.t.,

Table 3 Cost Comparison between Own Feeder Service and Common Feeder service under Different Allocation Lifting. (Source: authors)

\begin{tabular}{|c|c|c|c|c|c|}
\hline Allocation & Head haul Lifting & Back haul Lifting & Own Feeder Cost & Common Feeder Cost & Cost Difference \\
\hline 1050 TEU & $100 \%$ & $80.00 \%$ & USD 474,600 & USD 503,160 & USD 28,560 \\
\hline 1050 TEU & $90 \%$ & $80.00 \%$ & USD 453,600 & USD 456,540 & USD 2940 \\
\hline 1050 TEU & $80 \%$ & $80.00 \%$ & USD 432,600 & USD 409,920 & USD $-22,680$ \\
\hline 1050 TEU & $70 \%$ & $80.00 \%$ & USD 411,600 & USD 363,300 & USD $-48,300$ \\
\hline \multicolumn{6}{|l|}{$1050 \mathrm{TEU}$} \\
\hline 1050 TEU & $100 \%$ & $70.00 \%$ & USD 470,400 & USD 498,540 & USD 28,140 \\
\hline 1050 TEU & $90 \%$ & $70.00 \%$ & USD 449,400 & USD 451,920 & USD 2520 \\
\hline 1050 TEU & $80 \%$ & $70.00 \%$ & USD 428,400 & USD 405,300 & USD $-23,100$ \\
\hline 1050 TEU & $70 \%$ & $70.00 \%$ & USD 407,400 & USD 358,680 & USD $-48,720$ \\
\hline \multicolumn{6}{|l|}{1050 TEU } \\
\hline 1050 TEU & $100 \%$ & $60.00 \%$ & USD 466,200 & USD 493,920 & USD 27,720 \\
\hline 1050 TEU & $90 \%$ & $60.00 \%$ & USD 445,200 & USD 447,300 & USD 2100 \\
\hline 1050 TEU & $80 \%$ & $60.00 \%$ & USD 424,200 & USD 400,680 & USD -23,520 \\
\hline 1050 TEU & $70 \%$ & $60.00 \%$ & USD 403,200 & USD 354,060 & USD $-49,140$ \\
\hline
\end{tabular}


$\mathrm{W}_{\mathrm{ij}}^{\mathrm{e}}+\mathrm{W}_{\mathrm{ij}}^{\mathrm{f}} \leq \mathrm{S}, \quad \forall \mathrm{i} \in \mathrm{I}, \mathrm{j} \in \mathrm{J}$

$\mathrm{W}_{\mathrm{ij}}^{\mathrm{f}} * \mathrm{~A}_{\mathrm{ij}}^{\mathrm{f}}+3.5 * \mathrm{~W}_{\mathrm{ij}}^{\mathrm{e}} \leq \mathrm{DW}, \forall \mathrm{i} \in \mathrm{I}, \mathrm{j} \in \mathrm{J}$

$\mathrm{D}_{\mathrm{ij}} / \mathrm{S}_{\mathrm{ij}} \leq 7, \forall \mathrm{i} \in \mathrm{I}, \mathrm{j} \in \mathrm{J}$

$R_{i j}^{f} \geq R_{i j,}^{e}, \forall i \in I, j \in J$

$P_{\mathrm{ij}}^{\mathrm{if}} \geq \mathrm{P}_{\mathrm{ij}}^{\mathrm{iee}}, \forall \mathrm{i} \in \mathrm{I}, \mathrm{j} \in \mathrm{J}$

$\mathrm{B}_{\mathrm{l}} \geq \mathrm{B}_{\mathrm{h}}$

$\sum \mathrm{F}_{\mathrm{ij}} \geq \sum \mathrm{L}_{\mathrm{ij}}$

$W_{i j}^{f}, W_{i j}^{e}, A_{i j}^{f}, R_{i j}^{f}, R_{i j}^{e}, P_{i j}^{i f}, P_{i j}^{i e}, T_{i j}^{i}, D_{i j}, S_{i j}, F_{i j}, L_{i j}, B_{h}, B_{l}, V, \geq 0$

Constraint (2) ensures the total containers transported are within the limitation of the vessel's allocation capacity. Constraint (3) guarantees the total containers transported are within the limitation of the vessel's weight capacity. Constraints (4) ensures the feeder service is on a weekly basis. As in practice, the revenue generated by fully loaded containers is always higher than that from empty containers; constraint (5) ensures this. Similarly, constraint (6) ensures the loading and discharging rate for fully loaded containers is higher than that from empty containers, constraint (7) guarantees the price of light oil is higher than that of heavy oil according to the rule in practice. Constraint (8) ensures that the heavy oil consumption in route network is larger than light oil according to the participative observation. Constraint (9) guarantees all variables are non-negative.

In addition, Santini et al. (2017) found that the cost incurred for a unit of time at speed $S_{i j}$ equals to third power of the value calculated by $S_{\mathrm{ij}}$ divided by design speed, and multiplied by the cost to sail for a unit of time at the design speed.

According to the conclusion of section 4.1, the own feeder network is more competitive in terms of saving cost than common feeder service only when the head haul allocation lifting is higher than $90 \%$. In order to provide sufficient cargo support and cover more out ports in the network, we propose four alternatives to connect Kotka with various ports. The alternative feeder networks are proposed and evaluated by the aforementioned system. Tables 4, 5, 6, and 7 present the alternatives.

Table 8 presents the cost comparison of the four alternatives. We deploy two vessels under Scheme 1, 2 and 3 while only one vessel for Scheme 4 as a result of different quantity of calling ports. The vessel cost is calculated by the market offer, and the fuel consumption is calculated by Company A's unit consumption of similar vessels and the sailing and berthing time of four alternatives. The port cost is calculated according to the vendor contracts between Company A and related ports.

Based on the traditional research of cost evaluation, and from the results in Table 8, we can conclude that the order of preference for the network design is Scheme 1, 2, 4, and 3. However, whether the decisions would be different if intra-European cargo revenue was considered remains a question. As intra-European business has strict limitations of delivery time and domestic business is generally handled by truck or rail, we identify the available routings under different schemes. Table 9 presents the effective routing by identifying the port pairs between a port and the subsequent three ports that do not belong to the same country.

We calculate the objective function value under different intra-European cargo volume scenarios from 10TEU to $700 \mathrm{TEU}$ per effective port pair routing. The average revenue for intra-Europe cargo is assumed to be USD300/TEU (in terms of Gate in/Gate out). Table 10 presents the comparison of four alternatives.

It is interesting that, when the intra-Europe volume is relatively low, Scheme 4 seems to be the best solution although the single allocation cost is not the lowest. This can be attributed to the lowest total sailing cost, which implies the necessity of controlling vessel deployment if no short-leg business is available. In addition, Scheme 2 seems to be a better solution than Scheme 3 when intraEurope cargo increases in the beginning. However, with the increase of intra-Europe cargo, Scheme 3 surpasses Scheme 2, and the gap widens gradually. Scheme $1 \mathrm{im}$ proves significantly with the increase of intra-Europe cargo and becomes a stable best solution. This is due to more effective routing than others, and a lower total sailing cost than Scheme 3. Figure 2 presents the evaluation of four feeder network alternatives under different scenarios of intra-European cargo.

The above model analyzes how intra-Europe cargo affects the feeder network work design and the conclusion is verified by numerical experiment. However, although the transit and buffer times are considered in the proposed network solution, the objective to promote equipment balance, maintain competitiveness and stability, and also the potential allocation utilization are not included in the evaluation system. We present a Grey correlation analysis in section 4.3.

\subsection{Grey relational evaluation (GRE)}

Grey relational evaluation (GRE) is a method to determine the influence or contribution of factors to a system corresponding to the degree of similarity or dissimilarity among factors. The Grey correlation degree is a measure of the correlation between two systems or two factors. If the trends of the two factors are consistent and the 
Table 4 Alternatives to connect Kotka with Russia and Denmark (Source: authors)

\begin{tabular}{|c|c|c|c|c|c|c|c|c|c|}
\hline \multirow[b]{2}{*}{ No. } & \multirow[b]{2}{*}{ Port } & \multicolumn{3}{|l|}{ Sea Way } & \multicolumn{2}{|c|}{ Pilot } & \multirow{2}{*}{$\begin{array}{l}\text { Berth } \\
\text { Time }\end{array}$} & \multicolumn{2}{|c|}{ Buffer } \\
\hline & & Distance & Speed & Time & $\ln$ & Out & & Sea & Port \\
\hline 1 & Hamburg & 0 & N/A & 0 & N/A & 0 & 22.0 & 0.0 & 0.0 \\
\hline 2 & Cbrun & 40 & 10 & 4.0 & 1.0 & 0.0 & 0.0 & 0.0 & 0.0 \\
\hline 3 & CKiel & 70 & 10 & 7.0 & 0.0 & 1.0 & 0.0 & 0.0 & 0.0 \\
\hline 4 & ST Petersburg & 764 & 16 & 47.8 & 4.0 & 4.0 & 24.0 & 0.0 & 0.0 \\
\hline 5 & Kotka & 114 & 16 & 7.1 & 1.0 & 1.0 & 19.0 & 0.0 & 0.0 \\
\hline 6 & Helsinki & 69 & 16 & 4.3 & 1.0 & 1.0 & 19.0 & 0.0 & 0.0 \\
\hline 7 & CKiel & 618 & 16 & 38.6 & 1.0 & 0.0 & 0.0 & 0.0 & 0.0 \\
\hline 8 & Cbrun & 70 & 10 & 7.0 & 0.0 & 1.0 & 0.0 & 0.0 & 0.0 \\
\hline 9 & Hamburg & 40 & 10 & 4.0 & 1.0 & 1.0 & 22.0 & 0.0 & 0.0 \\
\hline 10 & Cbrun & 40 & 10 & 4.0 & 1.0 & 0.0 & 0.0 & 0.0 & 0.0 \\
\hline 11 & Ckiel & 70 & 10 & 7.0 & 0.0 & 1.0 & 0.0 & 0.0 & 0.0 \\
\hline 12 & Aarhus & 125 & 16 & 7.8 & 1.0 & 1.0 & 19.0 & 0.0 & 0.0 \\
\hline 13 & Copenhagen & 106 & 16 & 6.6 & 1.0 & 1.0 & 18.0 & 0.0 & 0.0 \\
\hline 14 & Ckiel & 153 & 16 & 9.6 & 1.0 & 0.0 & 0.0 & 0.0 & 0.0 \\
\hline 15 & Cbrun & 70 & 10 & 7.0 & 0.0 & 1.0 & 0.0 & 0.0 & 0.0 \\
\hline 16 & Hamburg & 40 & 10 & 4.0 & 1.0 & 1.0 & 0.0 & 0.0 & 0.0 \\
\hline
\end{tabular}

degree of synchronous change is high, it means that the degree of correlation between them is high; otherwise, it is low. The main procedures of GRE are as follows:

(1) Determine the optimal set of indicators. Set $\mathrm{F}=\left[\mathrm{j}_{1}^{*}\right.$ , $\left.\mathrm{j}_{2}^{*} \ldots \mathrm{j}_{\mathrm{n}}^{*}\right], \mathrm{j}_{\mathrm{k}}^{*}$ represents the optimal value of the $\mathrm{k}$-th indicator. After selecting the optimal set, we can construct a matrix D:

$$
D=\left[\begin{array}{cccc}
j_{1}{ }^{*} & j_{2}{ }^{*} & \cdots & j_{n}{ }^{*} \\
j_{1}{ }^{1} & j_{2}{ }^{1} & \cdots & j_{n}{ }^{1} \\
\vdots & \vdots & & \vdots \\
j_{1}{ }^{m} & j_{2}{ }^{m} & \cdots & j_{n}{ }^{m}
\end{array}\right]
$$

Among them, $\mathrm{j}_{\mathrm{k}}^{\mathrm{i}}$ is the original value of the $\mathrm{k}$-th indicator of the i-th feeder network solution.

Table 5 Alternatives to connect Kotka with Russia and Poland (Source: authors)

\begin{tabular}{|c|c|c|c|c|c|c|c|c|c|}
\hline \multirow[b]{2}{*}{ No. } & \multirow[b]{2}{*}{ Port } & \multicolumn{3}{|l|}{ Sea Way } & \multicolumn{2}{|c|}{ Pilot } & \multirow{2}{*}{$\begin{array}{l}\text { Berth } \\
\text { Time }\end{array}$} & \multicolumn{2}{|c|}{ Buffer } \\
\hline & & Distance & Speed & Time & In & Out & & Sea & Port \\
\hline 1 & Hamburg & 0 & N/A & 0 & N/A & 0 & 24.0 & 0.0 & 0.0 \\
\hline 2 & Cbrun & 40 & 10.0 & 4.0 & 1.0 & 0.0 & 0.0 & 0.0 & 0.0 \\
\hline 3 & CKiel & 70 & 10.0 & 7.0 & 0.0 & 1.0 & 0.0 & 0.0 & 0.0 \\
\hline 4 & ST Petersburg & 764 & 16.0 & 47.8 & 4.0 & 4.0 & 24.0 & 0.0 & 0.0 \\
\hline 5 & Kotka & 114 & 16.0 & 7.1 & 1.0 & 1.0 & 24.0 & 0.0 & 0.0 \\
\hline 6 & CKiel & 674 & 16.0 & 42.1 & 1.0 & 0.0 & 0.0 & 0.0 & 0.0 \\
\hline 7 & Cbrun & 70 & 10.0 & 7.0 & 1.0 & 0.0 & 0.0 & 0.0 & 0.0 \\
\hline 8 & Hamburg & 40 & 10.0 & 4.0 & 0.0 & 0.0 & 24.0 & 0.0 & 0.0 \\
\hline 9 & Cbrun & 40 & 10.0 & 4.0 & 1.0 & 0.0 & 0.0 & 0.0 & 0.0 \\
\hline 10 & Ckiel & 70 & 10.0 & 7.0 & 0.0 & 1.0 & 0.0 & 0.0 & 0.0 \\
\hline 11 & Gdynia & 329 & 16.0 & 20.5 & 1.0 & 1.0 & 17.0 & 0.0 & 0.0 \\
\hline 12 & Gdansk & 25 & 16.0 & 1.6 & 1.0 & 1.0 & 17.5 & 0.0 & 0.0 \\
\hline 13 & Ckiel & 330 & 16.0 & 20.6 & 1.0 & 0.0 & 0.0 & 0.0 & 0.0 \\
\hline 14 & Cbrun & 70 & 10.0 & 7.0 & 0.0 & 1.0 & 0.0 & 0.0 & 0.0 \\
\hline 15 & Hamburg & 40 & 10.0 & 4.0 & 0.0 & 0.0 & 0.0 & 0.0 & 0.0 \\
\hline
\end{tabular}


Table 6 Alternatives to connect Kotka with double hub ports and Denmark (Source: authors)

\begin{tabular}{|c|c|c|c|c|c|c|c|c|c|}
\hline \multirow[b]{2}{*}{ No. } & \multirow[b]{2}{*}{ Port } & \multicolumn{3}{|l|}{ Sea Way } & \multicolumn{2}{|c|}{ Pilot } & \multirow{2}{*}{$\begin{array}{l}\text { Berth } \\
\text { Time }\end{array}$} & \multicolumn{2}{|c|}{ Buffer } \\
\hline & & Distance & Speed & Time & In & Out & & Sea & Port \\
\hline 1 & Rotterdam & 0 & N/A & 0 & N/A & 1.0 & 18.0 & 0.0 & 0.0 \\
\hline 2 & Hamburg & 300 & 16.0 & 18.8 & 6.0 & 0.0 & 18.0 & 0.0 & 0.0 \\
\hline 3 & Cbrun & 40 & 10.0 & 4.0 & 1.0 & 0.0 & 0.0 & 0.0 & 0.0 \\
\hline 4 & CKiel & 70 & 10.0 & 7.0 & 0.0 & 1.0 & 0.0 & 0.0 & 0.0 \\
\hline 5 & Helsinki & 618 & 16.0 & 38.6 & 1.0 & 1.0 & 14.0 & 0.0 & 0.0 \\
\hline 6 & Kotka & 69 & 16.0 & 4.3 & 1.0 & 1.0 & 14.0 & 0.0 & 0.0 \\
\hline 7 & CKiel & 674 & 16.0 & 42.1 & 0.0 & 1.0 & 0.0 & 0.0 & 0.0 \\
\hline 8 & Cbrun & 70 & 10.0 & 7.0 & 0.0 & 0.0 & 0.0 & 0.0 & 0.0 \\
\hline 9 & Hamburg & 40 & 10.0 & 4.0 & 0.0 & 0.0 & 24.0 & 0.0 & 0.0 \\
\hline 10 & Cbrun & 40 & 10.0 & 4.0 & 1.0 & 0.0 & 0.0 & 0.0 & 0.0 \\
\hline 11 & Ckiel & 70 & 10.0 & 7.0 & 0.0 & 1.0 & 0.0 & 0.0 & 0.0 \\
\hline 12 & Aarhus & 125 & 16.0 & 6.6 & 1.0 & 1.0 & 20.0 & 0.0 & 0.0 \\
\hline 13 & Copenhagen & 106 & 16.0 & 6.6 & 1.0 & 1.0 & 20.0 & 0.0 & 0.0 \\
\hline 14 & Ckiel & 153 & 16.0 & 9.6 & 1.0 & 0.0 & 0.0 & 0.0 & 0.0 \\
\hline 15 & Cbrun & 70 & 10.0 & 7.0 & 0.0 & 1.0 & 0.0 & 0.0 & 0.0 \\
\hline 16 & Rotterdam & 255 & 16.0 & 15.9 & 1.0 & 1.0 & 0.0 & 0.0 & 0.0 \\
\hline
\end{tabular}

(2) Standardized treatment of indicators. There are usually different dimensions and orders of magnitude among the evaluation indicators and the original indicators need to be standardized. The original value can be transformed into a dimensionless value by the formula below.

$$
C_{k}^{i}=\frac{\max _{i} j_{k}^{i}-j_{k}^{i}}{\max _{i} j_{k}^{i}-\min _{i}^{i} j_{k}^{i}}
$$

Indicators of lower abstinence type:

Where, $i=1,2,3, \ldots m ; j=1,2,3, \ldots n$.

The matrix from which $\mathrm{D}$ can be transformed into $\mathrm{C}$ is:

$$
C_{k}^{i}=\frac{j_{k}^{i}-\min _{i} j_{k}^{i}}{\max _{i} j_{k}^{i}-\min _{i}^{i} j_{k}^{i}}
$$

$$
C=\left[\begin{array}{cccc}
C_{1}{ }^{*} & C_{2}{ }^{*} & \cdots & C_{n}{ }^{*} \\
C_{1}{ }^{1} & C_{2}{ }^{1} & \cdots & C_{n}{ }^{1} \\
\vdots & \vdots & & \vdots \\
C_{1}{ }^{m} & C_{2}{ }^{m} & \cdots & C_{n}{ }^{m}
\end{array}\right]
$$

\begin{tabular}{|c|c|c|c|c|c|c|c|c|c|}
\hline \multirow[b]{2}{*}{ No. } & \multirow[b]{2}{*}{ Port } & \multicolumn{3}{|l|}{ Sea Way } & \multicolumn{2}{|c|}{ Pilot } & \multirow{2}{*}{$\begin{array}{l}\text { Berth } \\
\text { Time }\end{array}$} & \multicolumn{2}{|c|}{ Buffer } \\
\hline & & Distance & Speed & Time & $\ln$ & Out & & Sea & Port \\
\hline 1 & Rotterdam & 0 & N/A & 0 & $\mathrm{~N} / \mathrm{A}$ & 1.0 & 20.0 & 0.0 & 0.0 \\
\hline 2 & Hamburg & 300 & 16.0 & 18.8 & 6.0 & 1.0 & 18.0 & 0.0 & 0.0 \\
\hline 3 & Cbrun & 40 & 10.0 & 4.0 & 1.0 & 0.0 & 0.0 & 0.0 & 0.0 \\
\hline 4 & CKiel & 70 & 10.0 & 7.0 & 0.0 & 2.0 & 0.0 & 0.0 & 0.0 \\
\hline 5 & Copenhagen & 153 & 16.0 & 9.6 & 1.0 & 1.0 & 15.0 & 0.0 & 0.0 \\
\hline 6 & Aarhus & 106 & 16.0 & 6.6 & 1.0 & 1.0 & 15.0 & 0.0 & 0.0 \\
\hline 7 & CKiel & 125 & 16.0 & 7.8 & 0.0 & 0.0 & 0.0 & 0.0 & 0.0 \\
\hline 8 & Cbrun & 70 & 10.0 & 7.0 & 1.0 & 3.5 & 0.0 & 0.0 & 0.0 \\
\hline 9 & Rotterdam & 300 & 16.0 & 18.8 & 1.0 & 0.0 & 0.0 & 0.0 & 0.0 \\
\hline
\end{tabular}

Indicators of upper abstinence type:

Table 7 Alternatives without Kotka with double hub ports connection (Source: authors) 
Table 8 Cost comparison between Four Alternatives of Feeder Network Design (Source: authors)

\begin{tabular}{|c|c|c|c|c|}
\hline Vessel Type & Scheme 1 & Scheme 2 & Scheme 3 & Scheme 4 \\
\hline \multicolumn{5}{|l|}{ Vessel Cost } \\
\hline Vessel Rental Cost & $\$ 6000 /$ Day $^{*} 2$ & $\$ 6000 / \mathrm{Day}^{*} 2$ & $\$ 6000 / D a{ }^{*} 2$ & $\$ 6000 /$ Day $^{*} 1$ \\
\hline Full Voyage Time & 7 Day & 7 Day & 7 Day & 7 Day \\
\hline Vessel Cost in Total & $\$ 84,000$ & $\$ 84,000$ & $\$ 84,000$ & $\$ 42,000$ \\
\hline \multicolumn{5}{|l|}{ Fuel cost } \\
\hline Fuel Consumption on Sailing & 276.33 Ton & 306.17 Ton & 304.17 Ton & 132.67 Ton \\
\hline Fuel Consumption on Berthing & 29.79 Ton & 27.19 Ton & 26.67 Ton & 14.17 Ton \\
\hline Sailing Time on Sea & 165.8 Hour & 183.7 Hour & 182.5 Hour & 79.6 Hour \\
\hline Berthing Time on Port & 143 Hour & 130.5 Hour & 128 Hour & 68 Hour \\
\hline Price of Heavy Oil & $\$ 650 /$ Ton & $\$ 650 /$ Ton & $\$ 650 /$ Ton & $\$ 650 /$ Ton \\
\hline Price of Light Oil & $\$ 1000 /$ Ton & $\$ 1000 /$ Ton & $\$ 1000 /$ Ton & $\$ 1000 /$ Ton \\
\hline Fuel Cost in Total & $209,404.5$ & $226,200.5$ & $224,380.5$ & $100,405.5$ \\
\hline \multicolumn{5}{|l|}{ Port Cost } \\
\hline Port Cost of Hamburg & $\$ 26,000$ & $\$ 26,000$ & $\$ 26,000$ & $\$ 13,000$ \\
\hline Port Cost of ST Petersburg & $\$ 12,000$ & $\$ 12,000$ & N/A & N/A \\
\hline Port Cost of Kotka & $\$ 13,000$ & $\$ 13,000$ & $\$ 13,000$ & N/A \\
\hline Port Cost of Helsinki & $\$ 13,000$ & N/A & $\$ 13,000$ & N/A \\
\hline Port Cost of Aarhus & $\$ 13,000$ & N/A & $\$ 13,000$ & $\$ 13,000$ \\
\hline Port Cost of Copenhagen & $\$ 13,000$ & N/A & $\$ 13,000$ & $\$ 13,000$ \\
\hline Port Cost of Gdynia & N/A & $\$ 13,000$ & N/A & N/A \\
\hline Port Cost of Gdansk & N/A & $\$ 13,000$ & N/A & N/A \\
\hline Port Cost of Rotterdam & N/A & N/A & $\$ 13,000$ & $\$ 13,000$ \\
\hline Port Cost of Kiel Canal & $\$ 30,000$ & $\$ 30,000$ & $\$ 30,000$ & $\$ 15,000$ \\
\hline Port Cost in Total & $\$ 120,000$ & $\$ 107,000$ & $\$ 121,000$ & $\$ 67,000$ \\
\hline Total Sailing Cost & $\$ 413,404.5$ & $\$ 417,200.5$ & $\$ 429,380.5$ & $\$ 209,405.5$ \\
\hline Available Capacity & $1050 * 2$ TEU & $1050 * 2$ TEU & $1050 * 2$ TEU & $1050 * 1$ TEU \\
\hline Single Allocation Cost & \$ 196.8 & \$ 198.7 & $\$ 204.4$ & $\$ 199.4$ \\
\hline
\end{tabular}

(3) Calculation of Grey correlation coefficient. According to the Grey relational theory, we take $\left\{C^{*}\right\}=\left[C_{1}^{*}, C_{2}^{*}, \quad, C_{n}^{*}\right]$ as the reference sequence, and take $\{C\}=\left[C_{1}^{i}, C_{2}{ }^{i}, \quad, C_{n}{ }^{i}\right]$ as the comparative sequence. The correlation coefficients of the k-th indicator and the $\mathrm{k}$-th optimal indicator of the $\mathrm{i}$-th scheme are obtained using the correlation analysis method as follows:

$$
\xi \mathrm{i}(k)=\frac{\min _{i} \min _{k}\left|C_{k}{ }^{*}-C_{k}{ }^{i}\right|+p \max _{i} \max _{k}\left|C_{k}{ }^{*}-C_{k}{ }^{i}\right|}{\left|C_{k}{ }^{*}-C_{k}{ }^{i}\right|+p \max _{i} \max _{k}\left|C_{k}{ }^{*}-C_{k}{ }^{i}\right|}
$$

(4) Determine the weight of each indicator. The indicator weight can be determined by the combination of expert investigation and the analytic hierarchy process (AHP). $w=\left\{w_{k} / k=1,2, \quad, n\right\}, \mathrm{w}_{\mathrm{k}}$ is the $\mathrm{k}$-th indicator weight.

(5) Establish the degree of Grey correlation and the evaluation result. According to the formula $\mathrm{R}=$ $\mathrm{W} \times \mathrm{E}^{\mathrm{T}}$, calculate the final correlation between the single layer and the multilayer.

(Note) $R=\left[r_{1}, r_{2}, \cdots, r_{m}\right]^{T}$ is the comprehensive evaluation result vector for $M$ subjects, E serves as the evaluation matrix of each indicator. 
Table 9 Available Intra-Europe Routing under Four Alternatives of Feeder Network Design (Source: authors)

\begin{tabular}{|c|c|c|c|c|}
\hline & Scheme 1 & Scheme 2 & Scheme 3 & Scheme 4 \\
\hline 1 & Hamburg-ST Petersburg & Hamburg-ST Petersburg & Rotterdam-Hamburg & Rotterdam-Hamburg \\
\hline 2 & Hamburg-Kotka & Hamburg-Kotka & Rotterdam-Helsinki & Rotterdam-Copenhagen \\
\hline 3 & Hamburg-Helsinki & ST Petersburg-Kotka & Rotterdam-Kotka & Rotterdam-Aarhus \\
\hline 4 & ST Petersburg-Kotka & ST Petersburg-Hamburg & Hamburg-Helsinki & Hamburg-Copenhagen \\
\hline 5 & ST Petersburg-Helsinki & ST Petersburg-Gdynia & Hamburg-Kotka & Hamburg-Aarhus \\
\hline 6 & ST Petersburg-Hamburg & Kotka-Hamburg & Helsinki-Hamburg & Hamburg-Rotterdam \\
\hline 7 & Kotka-Hamburg & Kotka-Gdynia & Helsinki-Aarhus & Copenhagen-Rotterdam \\
\hline 8 & Kotka-Aarhus & Kotka-Gdansk & Kotka-Hamburg & Copenhagen-Hamburg \\
\hline 9 & Helsinki-Hamburg & Hamburg-Gdynia & Kotka-Aarhus & Aarhus-Rotterdam \\
\hline 10 & Helsinki-Aarhus & Hamburg-Gdansk & Kotka-Copenhagen & Aarhus-Hamburg \\
\hline 11 & Helsinki-Copenhagen & Gdynia-Hamburg & Hamburg-Aarhus & \\
\hline 12 & Hamburg-Aarhus & Gdynia-ST Petersburg & Hamburg-Copenhagen & \\
\hline 13 & Hamburg-Copenhagen & Gdansk-Hamburg & Hamburg-Rotterdam & \\
\hline 14 & Aarhus-Hamburg & Gdansk-ST Petersburg & Aarhus-Rotterdam & \\
\hline 15 & Aarhus-ST Petersburg & Gdansk-Kotka & Aarhus-Hamburg & \\
\hline 16 & Copenhagen-Hamburg & & Copenhagen-Rotterdam & \\
\hline 17 & Copenhagen-ST Petersburg & & Copenhagen-Hamburg & \\
\hline 18 & Copenhagen-Kotka & & Copenhagen-Helsinki & \\
\hline
\end{tabular}

$$
E=\left[\begin{array}{cccc}
\xi_{1}(1) & \xi_{1}(2) & \cdots & \xi_{1}(\mathrm{n}) \\
\xi_{2}(1) & \xi_{2}(2) & \cdots & \xi_{2}(\mathrm{n}) \\
\vdots & \vdots & \vdots & \\
\xi_{m}(1) & \xi_{m}(2) & \cdots & \xi_{m}(\mathrm{n})
\end{array}\right]
$$

Where $\varepsilon_{\mathrm{i}}(\mathrm{k})$ is the correlation coefficient between the $\mathrm{k}$-th index and the $\mathrm{k}$-th optimal index of the $\mathrm{i}$-th scheme. If the ultimate correlation is the maximum, the scheme is superior to others. The sequence of the evaluated schemes can be arranged in order from superiority to inferiority.

According to section 4.2, to meet the objective of feeder network design, single allocation cost (SAC),

Table 10 Objective Function Value of Scheme 2 under Different IET Revenue Hypothesis (Source: authors)

\begin{tabular}{|c|c|c|c|c|c|c|c|c|}
\hline \multirow{2}{*}{$\begin{array}{l}\text { IET Cargo } \\
\text { Hypothesis }\end{array}$} & \multicolumn{2}{|l|}{ Scheme 1} & \multicolumn{2}{|l|}{ Scheme 2} & \multicolumn{2}{|l|}{ Scheme 3} & \multicolumn{2}{|l|}{ Scheme 4} \\
\hline & $\begin{array}{l}\text { IET } \\
\text { Revenue }\end{array}$ & $\begin{array}{l}\text { Objective Function } \\
\text { Value }\end{array}$ & $\begin{array}{l}\text { IET } \\
\text { Revenue }\end{array}$ & $\begin{array}{l}\text { Objective Function } \\
\text { Value }\end{array}$ & $\begin{array}{l}\text { IET } \\
\text { Revenue }\end{array}$ & $\begin{array}{l}\text { Objective } \\
\text { Function Value }\end{array}$ & $\begin{array}{l}\text { IET } \\
\text { Revenue }\end{array}$ & $\begin{array}{l}\text { Objective } \\
\text { Function Value }\end{array}$ \\
\hline $10 \mathrm{TEU}$ & 54,000 & $-359,405$ & 45,000 & $-372,201$ & 54,000 & $-375,381$ & 30,000 & $-179,405.5$ \\
\hline 50 TEU & 270,000 & $-143,405$ & 225,000 & $-192,201$ & 270,000 & $-159,381$ & 150,000 & $-59,405.5$ \\
\hline 100 TEU & 540,000 & $126,595.5$ & 450,000 & $32,799.5$ & 540,000 & $110,619.5$ & 300,000 & $90,594.5$ \\
\hline 150 TEU & 810,000 & $396,595.5$ & 675,000 & $257,799.5$ & 810,000 & $380,619.5$ & 450,000 & $240,594.5$ \\
\hline 200 TEU & $1,080,000$ & $666,595.5$ & 900,000 & $482,799.5$ & $1,080,000$ & $650,619.5$ & 600,000 & $390,594.5$ \\
\hline 250 TEU & $1,350,000$ & $936,595.5$ & $1,125,000$ & $707,799.5$ & $1,350,000$ & $920,619.5$ & 750,000 & $540,594.5$ \\
\hline 300 TEU & $1,620,000$ & $1,206,596$ & $1,350,000$ & $932,799.5$ & $1,620,000$ & $1,190,620$ & 900,000 & $690,594.5$ \\
\hline 350 TEU & $1,890,000$ & $1,476,596$ & $1,575,000$ & $1,157,800$ & $1,890,000$ & $1,460,620$ & $1,050,000$ & $840,594.5$ \\
\hline 400 TEU & $2,160,000$ & $1,746,596$ & $1,800,000$ & $1,382,800$ & $2,160,000$ & $1,730,620$ & $1,200,000$ & $990,594.5$ \\
\hline 450 TEU & $2,430,000$ & $2,016,596$ & $2,025,000$ & $1,607,800$ & $2,430,000$ & $2,000,620$ & $1,350,000$ & $1,140,594.5$ \\
\hline 500 TEU & $2,700,000$ & $2,286,596$ & $2,250,000$ & $1,832,800$ & $2,700,000$ & $2,270,620$ & $1,500,000$ & $1,290,594.5$ \\
\hline 550 TEU & $2,970,000$ & $2,556,596$ & $2,475,000$ & $2,057,800$ & $2,970,000$ & $2,540,620$ & $1,650,000$ & $1,440,594.5$ \\
\hline 600 TEU & $3,240,000$ & $2,826,596$ & $2,700,000$ & $2,282,800$ & $3,240,000$ & $2,810,620$ & $1,800,000$ & $1,590,594.5$ \\
\hline 650 TEU & $3,510,000$ & $3,096,596$ & $2,925,000$ & $2,507,800$ & $3,510,000$ & $3,080,620$ & $1,950,000$ & $1,740,594.5$ \\
\hline 700 TEU & $3,780,000$ & $3,366,596$ & $3,150,000$ & $2,732,800$ & $3,780,000$ & $3,350,620$ & $2,100,000$ & $1,890,594.5$ \\
\hline
\end{tabular}




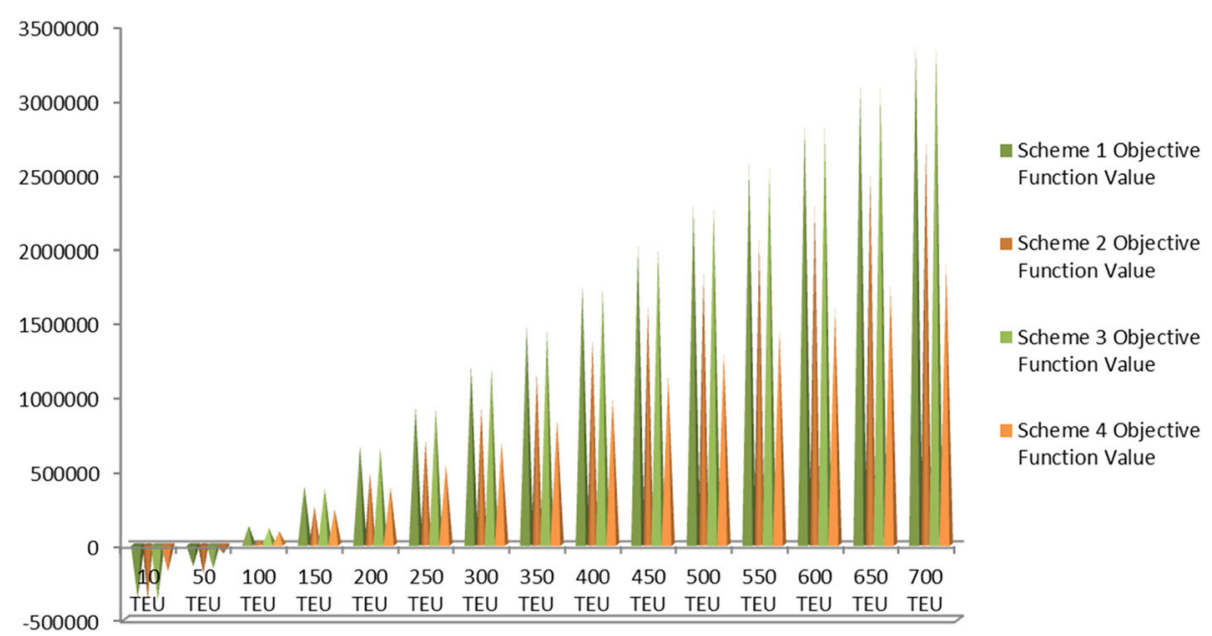

Fig. 2 Evaluation of Four Alternatives under Different Hypothesis of Intra-European Cargo (Source: authors)

sailing cycle (SC), equipment balance (EB), allocation utilization (AU), intra-Europe cargo revenue (IER), service route competitiveness (SRC), and service stability (SS) are selected as the indicators for decision making. Correspondingly, Z1, Z2, Z3, Z4, Z5, Z6, and Z7 are used to represent the indicators of SAC, SC, EB, AU, IER, SRC, and SS, respectively (i.e., Table 11).

We use S1, S2, S3, and S4 to represent Schemes 1, 2, 3 , and 4, respectively. Table 12 presents the original data as known in advance by static calculation and expert consultation.

According to the GRE method, the original data are normalized and the optimal reference sequence is determined, as shown in Table 13.

According to formula (14), we calculate the Grey correlation coefficient of normalized data and reference sequence as shown in Table 14.
The weight of each evaluation indicator is determined by expert consultation and the AHP method. We select eight experts in this field to make score separately for the degree of importance of the indicators. The results are then further discussed and summarized internally to obtain the judgment matrix. The maximum Eigen value of the judgment matrix es calculated using MATLAB software to check the consistency of the judgment matrix and verify the rationality of weight coefficients. We omit the calculation process and present the weight of each evaluation indicator as Table 15 .

In combination with the weight in Table 15 and the single indicator of Grey correlation in Table 14, we can determine the final Grey correlation and the evaluation result accordingly, as shown in Table 16.

Table 11 Indicators of Feeder Network Scheme Evaluation (Source: authors)

\begin{tabular}{|c|c|c|}
\hline Indicators & Index Definition and Type & Data Source \\
\hline $\begin{array}{l}\text { Single Allocation Cost } \\
\text { (SAC) }\end{array}$ & $\begin{array}{l}\text { The average single allocation cost of feeder network. } \\
\text { Indicators of upper abstinence type. }\end{array}$ & $\begin{array}{l}\text { Statically } \\
\text { calculation }\end{array}$ \\
\hline Sailing Cycle (SC) & $\begin{array}{l}\text { The average time to complete a roundtrip sailing. } \\
\text { Indicators of lower abstinence type. }\end{array}$ & $\begin{array}{l}\text { Statically } \\
\text { calculation }\end{array}$ \\
\hline Equipment Balance (EB) & $\begin{array}{l}\text { The ratio of import volume to export volume throughout the ports along the service route. } \\
\text { Indicators of upper abstinence type. }\end{array}$ & $\begin{array}{l}\text { Statically } \\
\text { calculation }\end{array}$ \\
\hline Allocation Utilization (AU) & $\begin{array}{l}\text { The ratio of total cargo transported to corresponding allocation of feeder network. } \\
\text { Indicators of lower abstinence type. }\end{array}$ & $\begin{array}{l}\text { Statically } \\
\text { calculation }\end{array}$ \\
\hline $\begin{array}{l}\text { Intra-Europe Cargo } \\
\text { Revenue (IER) }\end{array}$ & $\begin{array}{l}\text { The revenue generated from the Intra-Europe cargos. } \\
\text { Indicators of lower abstinence type. }\end{array}$ & $\begin{array}{l}\text { Statically } \\
\text { calculation }\end{array}$ \\
\hline $\begin{array}{l}\text { Service Route } \\
\text { Competitiveness (SRC) }\end{array}$ & $\begin{array}{l}\text { The comprehensive competitiveness of the service routes, with emphasis on delivery time, on-time per- } \\
\text { formance, frequency, and the connection with trunk lines. }\end{array}$ & $\begin{array}{l}\text { Expert } \\
\text { consultation }\end{array}$ \\
\hline Service Stability (SS) & $\begin{array}{l}\text { The route maintains stable service in line with the set calling ports, with emphasis on maintaining fixed } \\
\text { port service, and dealing with emergencies. }\end{array}$ & $\begin{array}{l}\text { Expert } \\
\text { consultation }\end{array}$ \\
\hline
\end{tabular}


Table 12 Original Data of Four Alternatives of Feeder Network (Source: authors)

\begin{tabular}{llllllll}
\hline & Z1 & Z2 & Z3 & Z4 & Z5 & Z6 & Z7 \\
\hline S1 & \$196.8/TEU & 308.8 Hours & $100 \%$ & $95 \%$ & $\$ 540,000$ & 95.3 & 89.1 \\
S2 & \$198.7/TEU & 314.2 Hours & $100 \%$ & $90 \%$ & $\$ 450,000$ & 88.7 & 87.3 \\
S3 & \$204.4/TEU & 310.5 Hours & $70 \%$ & $95 \%$ & $\$ 540,000$ & 93.1 & 96.3 \\
S4 & \$199.4/TEU & 147.6 Hours & $60 \%$ & $90 \%$ & $\$ 300,000$ & 91.4 & 92.7 \\
\hline
\end{tabular}

From Table 16, we can conclude that the order of preference for the network design is Scheme 3, 1, 2, and 4if all indicators of the feeder network objective are evaluated.

\section{Results and discussion}

A different priority for the feeder network scheme is presented in section 4. By evaluating the total sailing cost, the order of preference is found to be Scheme 4, 1, 2 and 3. This type of system is representative of the current research. The disadvantage lies in the lack of information on cost difference by the numbers of vessels deployed and calling ports, and it also fails to evaluate the impact of the extra cost on the revenue. The SAC evaluation system seems to improve the weakness of the above system as the total sailing cost is apportioned in the service route network. In this case study of section 4, the order of preference is Scheme 1, 2, 4 and 3 according to the order of SAC. Although this method is widely applied to practice, the impact of revenue generated by the additional service route is still not evaluated. By evaluating the revenue generated;the analysis reveals that certain cost increase is necessary and beneficial to the network design. This can be verified by the numerical experiment in section 4, Schemes 1 and 3 seem to be superior to other schemes as the result of more effective service routes. This advantage depends on the cargo transported, which is also reflected as the AU of effective port pairs. From the numerical experiment, the advantages of Schemes 1 and 3 can be realized only after a certain quantity of cargo is achieved. On this basis, we further investigate the service and efficiency indicators such as the EB, SRC, and stability. The priority of
Table 14 Grey Correlation Coefficient of Normalized Data and Reference Sequence (Source: authors)

\begin{tabular}{lllll}
\hline Indicators & S1 & S2 & S3 & S4 \\
\hline Z1 & 0.33 & 0.40 & 1.00 & 0.43 \\
Z2 & 0.94 & 1.00 & 0.96 & 0.33 \\
Z3 & 1.00 & 1.00 & 0.40 & 0.33 \\
Z4 & 1.00 & 0.33 & 1.00 & 0.33 \\
Z5 & 1.00 & 0.57 & 1.00 & 0.33 \\
Z6 & 1.00 & 0.33 & 0.60 & 0.46 \\
Z7 & 0.38 & 0.33 & 1.00 & 0.56 \\
\hline
\end{tabular}

Schemes 3 and 1 is found to be reversed. This can be attributed to the fact that the double hub ports design provides more possibilities for EB, optimizes the connection between feeder liners and trunk lines, and improves the competitiveness of the feeder network.

\section{Conclusion}

Feeder network design is best analyzed by a typical multi-objective decision-making model. In addition to the layout optimization of service routes, a feeder network provides efficient connection with trunk lines, establishing more effective port pairs to generate more revenue, improve equipment balance, and maintain the stability and competitiveness of the route. Therefore, the single objective evaluation model in the current researches has limitations. This study presents a multiobjective optimization model to reflect the main variables indicators for feeder network design. According to the Grey correlation method analysis, the allocation utilization seems to have a great impact in the decisionmaking process. This directs us to pay more attention to the efficiency of resource utilization in practice. Equipment balance and service stability both have significant impact as a result of the high correlation of these indicators with cost and customer service in feeder network design. The intra-regional cargo revenue is another key indicator that determines both feeder and trunk line de-
Table 15 Weight of Each Evaluation Indicator (Source: authors)

\begin{tabular}{ll}
\multicolumn{2}{l}{ Table 15 Weight of Each Evaluation Indicator (Source: authors) } \\
\hline Indicators & Weight of Indicators \\
\hline Single Allocation Cost (SAC) & 0.128 \\
Sailing Cycle (SC) & 0.128 \\
Equipment Balance (EB) & 0.159 \\
Allocation Utilization (AU) & 0.215 \\
Intra-Europe Cargo Revenue (IER) & 0.125 \\
Service Route Competitiveness (SRC) & 0.113 \\
Service Stability (SS) & 0.132 \\
\hline
\end{tabular}

\begin{abstract}
sign and has a major impact on the decision- making
\end{abstract}
Table 13 Normalized Data and the Optimal Reference Sequence (Source: authors)

\begin{tabular}{llllll}
\hline Indicators & S1 & S2 & S3 & S4 & Reference Sequence \\
\hline Z1 & 0.00 & 0.25 & 1.00 & 0.34 & 1 \\
Z2 & 0.97 & 1.00 & 0.98 & 0.00 & 1 \\
Z3 & 1.00 & 1.00 & 0.25 & 0.00 & 1 \\
Z4 & 1.00 & 0.00 & 1.00 & 0.00 & 1 \\
Z5 & 1.00 & 0.63 & 1.00 & 0.00 & 1 \\
Z6 & 1.00 & 0.00 & 0.67 & 0.41 & 1 \\
Z7 & 0.20 & 0.00 & 1.00 & 0.60 & 1 \\
\hline
\end{tabular}


Table 16 Final Grey Correlation and the Evaluation Result (Source: authors)

\begin{tabular}{lll}
\hline $\begin{array}{l}\text { Scheme to be } \\
\text { evaluated }\end{array}$ & $\begin{array}{l}\text { Final grey } \\
\text { correlation }\end{array}$ & $\begin{array}{l}\text { Order of } \\
\text { preference }\end{array}$ \\
\hline S1 & 0.826424 & 2 \\
S2 & 0.56329 & 3 \\
S3 & 0.853677 & 1 \\
S4 & 0.389341 & 4 \\
\hline
\end{tabular}

process as well. This indicates that it is important to evaluate the benefits of both long-haul and short-haul allocations in a practical service network layout. In a word, the objectives of service network design are diversified from the perspective of practical management. The multi-objective control model proposed in this paper reflects key factors in the actual decision-making process, which has significance for industry professionals.

This paper also has limitations as no sensitivity analysis was conducted to examine the sensitivity of each indicator. Further research is necessary to examine how a feeder network design is affected by extended cooperation and competition between both the members in shipping alliances and also the common feeder operators.

\section{Acknowledgements}

I would like to thank the reviewers for their constructive comments and editorial suggestions. I also thank Professor Wan Zheng and Professor Chen Jihong for their constructive suggestions.

\section{Authors' contributions}

X.F Wang, H. Hu, and H. Zhao analyzed and interpreted the data. Y. S Lin conceived and designed the analytic framework, and was a major contributor in writing the manuscript. The authors read and approved the final manuscript.

\section{Funding}

Funding information is not applicable.

\section{Availability of data and materials}

The datasets used during the current study are available from the corresponding author on reasonable request.

\section{Competing interests}

The authors declare that they have no competing interests.

\section{Author details}

'Logistics Engineering and Research Center, Shanghai Maritime University, Shanghai, China. ${ }^{2}$ Department of Transportation, Shipping and Logistics and State key Laboratory of Ocean Engineering, Shanghai Jiaotong University, Shanghai, China. ${ }^{3}$ Department of Civil and Environmental Engineering, National University of Singapore, Singapore, Singapore.

Received: 7 November 2019 Accepted: 20 October 2020

Published online: 09 November 2020

\section{References}

1. Akyüz, M. H., \& Lee, C. Y. (2016). Service type assignment and container routing with transit time constraints and empty container repositioning for liner shipping service networks. Transportation Research Part B: Methodological, 88, 46-71.
2. Gelarth, S., Maculan, N., Mahey, N., et al. (2013). Hub-and-spoke network design and fleet deployment for string planning of liner shipping. Applied Mathematical Modelling, 37(5), 3307-3321.

3. Everett, J., Hax, A., Lewison, V., \& Nutts, D. (1972). Optimization of a fleet of large tankers and bulkers: A linear programming approach. Marine Technology, 9, 430-438.

4. Perakis, A., \& Jaramillo, D. (1991). Fleet deployment optimization for liner shipping - Part 1. Background, problem formulation and solution approaches. Maritime Policy \&Management, 18(3), 183-200.

5. Meng, Q., Wang, S., Andersson, H., \& Thun, K. (2014). Containership routing and scheduling in liner shipping: Overview and future research directions. Transportation Science, 48(2), 265-280

6. Hwa-Joong, K., Lee, L. J. S., \& Tae-Woo, L. P. (2018). Analysis of liner shipping networks and transshipment flows of potential hub ports in sub-Saharan Africa. Transport Policy, 69, 193-206.

7. ShintaniK, I. A., Nishimura, E., et al. (2007). The container shipping network design problem with empty container repositioning. Transportation Research Part E Logistics \& Transportation Review, 43(1), 0-59.

8. Santini, A., Plum, C. E. M., \& Ropke, S. (2017). A branch-and-price approach to the feeder network design problem. European Journal of Operational Research, 264(2), 607-622.

9. Zhao, H., Meng, Q., \& Wang, Y. (2019). Exploratory data analysis for the cancellation of slot booking in intercontinental container liner shipping: A case study of Asia to US west coast service. Transportation Research Part C: Emerging Technologies, 106, 243-263.

10. Meng, Q., Wang, T., \& Wang, S. (2012). Short-term liner ship fleet planning with container transshipment and uncertain container shipment demand. European Journal of Operational Research, 223(1), 96-105.

11. Zheng, J., \& Yang, D. (2016). Hub-and-spoke network design for container shipping along the Yangtze River. Journal of Transport Geography, 55, 51-57.

12. Zhao, H., Hu, H., \& Lin, Y. (2016). Study on China-EU container shipping network in the context of Northern Sea route. Journal of Transport Geography, 53, 50-60.

13. Konings, R., Kreutzberger, E., \& Maras, V. (2013). Major considerations in developing a hub-and-spoke network to improve the cost performance of container barge transport in the hinterland: The case of the port of Rotterdam. Journal of Transport Geography, 29, 63-73.

\section{Publisher's Note}

Springer Nature remains neutral with regard to jurisdictional claims in published maps and institutional affiliations.

\section{Submit your manuscript to a SpringerOpen ${ }^{\circ}$ journal and benefit from:}

- Convenient online submission

- Rigorous peer review

- Open access: articles freely available online

- High visibility within the field

- Retaining the copyright to your article

Submit your next manuscript at $>$ springeropen.com 